\title{
Economic Democracy and the Quest of Net Neutrality in Indonesia
}

\author{
Arasy Pradana A. Azis* \\ Association of Indonesian Socio-Legal Studies, Indonesia
}

\begin{abstract}
Net neutrality has played critical issues in internet-based businesses, as it may stop Internet Service Providers (ISPs) from discriminating against certain legal internet contents, platforms, or services. This study argued that net neutrality has a strong relationship with economic democracy as the constitutional basis of the Indonesian economy. This study examined net neutrality and considered its possible adoption in Indonesia under economic democracy by justifying economic democracy required the state to build an inclusive economy as per political economy theory. It used a socio-legal method through an interdisciplinary study of law and political economy with conceptual and comparative approaches. The study showed that the idea of the internet as a level playing field was founding net neutrality. For instance, in the United States and across different Global South countries, net neutrality relied on three orders of no blocking, no throttling, and no paid prioritization, which provided equal access for everyone to create their opportunities. At this point, economic democracy and net neutrality made their cross-cut. Like net neutrality, a discriminatory action against a content provider violated economic democracy, where policy-makers formulated economic policies to enable a level playing field for economic actors. Minimum barriers to entering the market might create such a level playing field. Without net neutrality, ISPs could carry out arbitrary actions and abuse of power for business interests. This study concluded that the adoption of net neutrality into formal regulation created a positive climate of innovation in the digital business ecosystem in Indonesia.
\end{abstract}

KEYWORDS: Economic Democracy, Net Neutrality, Digital Economy.

HOW TO CITE:

Azis, Arasy Pradana A., "Economic Democracy and the Quest of Net Neutrality in Indonesia" (2021) 8:3 Lentera Hukum 387-416. DOI: <https://doi.org/ 10.19184/ejlh. v8i3.26864>.

Submitted: 07/09/2021 Reviewed: 20/09/2021 Revised: 25/11/2021 Accepted: 26/11/2021

* Corresponding author’s e-mail: arasyaziz@gmail.com 


\section{INTRODUCTION}

Net neutrality is proposed as a foundational principle to create an inclusive and level playing field for internet-based businesses. The key proposal of net neutrality is the advocacy of zero-pricing to the internet, which prohibited the Internet Service Providers (ISPs) from charging the extra expense to the developer for delivering their contents or services through the broadband ISPs provided. ${ }^{1}$ Then, net neutrality relies on three critical orders: no blocking, throttling, and paid prioritization. It aims to ensure that everyone can start a business online with fewer barriers without fear of being decapitated by well-established platforms with more significant capital. ${ }^{2}$ Several countries have adopted the principle as an internet-related public policy, including those in the Global South.

In Indonesia, net neutrality is relatively an under-discussed topic. It is searched less than 100 times on Google every month. ${ }^{3}$ At the same time, only a few legal studies in Indonesia have addressed this issue; among them were written by Permana ${ }^{4}$ and Yosuadi. ${ }^{5}$ Permana argued network neutrality has not yet become the regulatory standard in internet governance. ${ }^{6}$ Neither Law 11/2008 of Electronic Information and Transaction Law and its amendment nor Law 5/1999 of Prohibition of Monopoly Practices and Unfair Business Competition (Anti-monopoly Law) outlined and regulated net neutrality. ${ }^{7}$ In the meantime, Yosuadi

1 C Scott Hemphill, "Network Neutrality and the False Promise of Zero-Price Regulation" (2008) 25:2 Yale Journal on Regulation at 137.

2 Sarah DeAgostino, "Neutrality in the Modern World: Internet Regulation's Impact on Economics and Society" (2020) 10:1 Notre Dame Journal of International \& Comparative Law at 197.

3 Google, "Google Trends Indonesia: Net Neutrality," online: <https://trends.google. $\mathrm{com} /$ trends/explore?q=net\%20neutrality\&geo=ID>.

4 Rizky Banyualam Permana, "Network Neutrality: Standar Baru dalam Tata Kelola Internet?" (2019) 31:3 Mimbar Hukum.

5 Dolok Yosuadi, "Problematika Prinsip Net Neutrality Berkenaan Layanan Jasa Netflix Pada Regulasi Nasional Indonesia” (2021) 7:1 Morality: Jurnal Ilmu Hukum.

6 Permana, supra note 4.

$7 \quad$ Ibid at 463. 
argued that the policy-maker should address net neutrality, reflecting the Telkom Group vs. Netflix case. ${ }^{8}$

At the beginning of its presence in Indonesia, Netflix was immediately blocked by the Telkom Group because it was deemed to contain content that violated moral norms. Netflix was also considered not to have a business license to operate in Indonesia. This dispute led to a trial by the Commission for the Supervision of Business Competition (KPPU) panel. In its decision, KPPU's panel stated that Telkom Group had not made a mistake. KPPU acknowledged that Telkom Group discriminated against Netflix by blocking users' access to their content while accessing another platform with similar services without barriers. However, KPPU was not considering such an action as a violation of the existing Anti-monopoly Law. ${ }^{9}$ In the end, KPPU released the Telkom Group from discriminatory charges.

Regardless of this final decision, the Telkom Group vs. Netflix case offered a critical precedent, raising the academic discourse of implementing net neutrality in Indonesia. Yosuadi's research focusing on regulating Over The Top (OTT) companies such as Netflix described this issue in a broader perspective, within the framework of the Indonesian economic constitution, as the latter should stand as a benchmark for every proposed regulation..$^{10}$ By its design, net neutrality is strongly related to economic democracy. As per definition, economic democracy is described by several characteristics, including the economy structured as a joint effort under kinship, and every citizen may develop their potential, initiative, and creativity within the boundaries that are not detrimental to the public

8 Yosuadi, supra note 5 at 1.

9 The Indonesian Commission for the Supervision of Business Competition Decision No 08/KPPU-I/2020 on Alleged Discriminatory Practices of Telekomunikasi Indonesia Inc. and Telekomunikasi Seluler Ltd. against Netflix, 2020 at 487 [Telkom Group vs. Netflix].

10 Ricca Anggraeni, "Memaknakan Fungsi Undang-Undang Dasar Secara Ideal dalam Pembentukan Undang-Undang”(2019) 48:3 Masalah-Masalah Hukum at 285. 
interest. ${ }^{11}$ The analysis of net neutrality under this economic constitution framework benefits the future proposal of regulatory change.

There will be a comparison between net neutrality practices, debates, and legal frameworks in the United States and several Global South countries like Chile, Brazil, and India. Hart considered the United States was the pioneer of this net neutrality debate. ${ }^{12}$ Meanwhile, the experiences of various Global South countries offer a valuable lesson. Indonesia, Chile, Brazil, and India have a similarity in having a huge percentage of internet users among their population. ${ }^{13}$ Several cases preceded the net neutrality in these countries with the same pattern as the Telkom Group vs. Netflix case. Brazil formally adopted net neutrality after several illegal throttling actions against Skype by two local ISPs. ${ }^{14}$ Learning from such experiences, Indonesia may follow its fellow Global South country moves by adopting the principle into a formal regulation.

This study aimed to examine net neutrality and consider its possible adoption in Indonesia under economic democracy. To that end, the analysis will begin by describing economic democracy as a fundamental constitutional framework of the Indonesian economy at large. The next section will provide an overview of net neutrality, from the internet economic system to why the principle of net neutrality is crucial to be highlighted. It will also analyze the adoption of net neutrality in the United States, Chile, Brazil, and India. This section will emphasize the alignment of economic democracy and net neutrality to encourage implementing net neutrality in Indonesia.

11 Tarmizi Abbas \& Win Konadi Manan, "Keterkaitan Antara Demokrasi Politik, Demokrasi Ekonomi, dan Sistem Ekonomi Kerakyatan" (2005) XXI:3 Mimbar at 431.

12 Jeffrey A Hart, "The Net Neutrality Debate in the United States" (2011) 8:4 Journal of Information Technology \& Politics at 418.

13 In 2021, more than $73 \%$ of Indonesian residents were internet users. While in India, for example, the number of internet users was expected to reach 500.90 million in 2023. Jasbir Singh, "Growth and Potential of Wireless Internet User in Rural India" (2021) 58:2 Psychology and Education: An Interdisciplinary Journal at 1010.

14 Nisha K De Lany, "From a Developing Country's Perspective: Is Net Neutrality a Non-Issue for South Africa?” (2017) 47:2 The University of the Pacific Law Review at 359 . 


\section{METHODS}

This study used a socio-legal method under the qualitative approach through an interdisciplinary study of law and political economy analysis. ${ }^{15}$ An interdisciplinary approach became important because net neutrality was a structural intervention within legal frameworks to create a fair and competitive digital economy ecosystem. Furthermore, this study adopted a conceptual approach by comprehending related statutes and legal cases with established net neutrality and comparing net neutrality regulations in the United States and several Global South countries, including Indonesia. ${ }^{16}$

\section{ECONOMIC DEMOCRACY AS THE FRAMEWORK OF THE INDONESIAN ECONOMY}

The term of economic democracy, as used in Article 33 (4) of the 1945 Constitution, has rooted in a long history of constitutional discourse, creating several different interpretations. Before the amendment of the constitution, economic democracy was assumed to expand people's participation in activities and management of economic resources. ${ }^{17}$ The policy-maker was designing the economy to pay more attention to the interests of the wider community. ${ }^{18}$ The Indonesian Constitutional Court interpreted economic democracy as state control over production that affects citizens' livelihood through proper and effective regulation, supervision, and management. ${ }^{19}$ Losses in production activities are still considered efficient as long as being subsidized and do not waste social

15 Muhammad Helmy Hakim, "Pergeseran Orientasi Penelitian Hukum: Dari Doktrinal ke Sosio-Legal” (2016) 16:2 Syariah: Jurnal Hukum dan Pemikiran at 108.

16 Meray Hendrik Mezak, "Jenis, Metode, dan Pendekatan Dalam Penelitian Hukum" (2006) 3:3 Law Review Fakultas Hukum Universitas Pelita Harapan at 92.

17 The 1945 Constitution at Art. 33.

18 M Dawam Rahardjo, Nalar Ekonomi Politik Indonesia (Bogor: IPB Press, 2011) at 87.

19 Adhi Anugroho, Ratih Lestarini \& Tri Hayati, "Analisis Yuridis Terhadap Asas Efisiensi Berkeadilan Berdasarkan Pasal 33 Ayat (4) UUD 1945 dalam Peraturan Perundang-Undangan di Bidang Ketenagalistrikan" (2017) 47:2 Jurnal Hukum \& Pembangunan at 197. 
resources. In other words, the state carries out losses in production to achieve the greatest prosperity for all the people, ${ }^{20}$ so that economic democracy is understood as the state of the government in ensuring equitable economic distribution.

According to Rahardjo, economic democracy has two frameworks, including inputs and outputs. Under the input framework, the distribution of access to economic resources, capital, and factors of production, including technology, indicates democracy in the economy. The key to economic democracy is equal distribution of employment opportunities and people's incomes. ${ }^{21}$ The system may allow workers to provide input and added value in the production process. On the output side, economic democracy permits fair income distribution. ${ }^{22}$

Dewantara interpreted economic democracy in Article 33 (4) of the 1945 Constitution as an economic system driven by the government's market mechanism. The government's role is not limited to a regulator. ${ }^{23}$ Under a democratic design, the government was also obliged to prevent market failures, externalities, and inequalities. The government is empowering all economic actors in a fair and balanced manner towards economic growth and equity. ${ }^{24}$ Economic democracy is established at the top of three foundations: distribution of assets, democratic economy organization, and equal collaboration. ${ }^{25}$ Yustika and Baksh emphasized that the democratic economic plan needs to create a level playing field between economic actors at the micro-level. ${ }^{26}$ Fair and healthy business competition is needed so that every economic actor gets a commensurate place.

In recent political economy discourses, such a healthy economic structure is also known as an inclusive economic institution. Under this economic

20 Ibid.

21 Rahardjo, supra note 18 at $87 \& 93$.

22 Ibid at 93.

23 Reka Dewantara, "Rekonseptualisasi Asas Demokrasi Ekonomi dalam Konstitusi Indonesia" (2014) 7:2 Arena Hukum at 197.

${ }^{24}$ Jimly Asshiddiqie, Konstitusi Ekonomi (Jakarta: Kompas, 2016) at 351.

25 Ahmad Erani Yustika \& Rukavina Baksh, Kebijakan Ekonomi: Regulasi, Institusi, Konstitusi (Malang: Intrans Publishing, 2021) at 72.

26 Ibid at 73. 
institution, many people are encouraged to participate in economic activities, make their own economic choice, and unleash their top ability and performance. The economic structure fulfills several criteria to ensure its inclusivity, including secure private property rights, a fair legal system, and a provision. ${ }^{27}$ It also provides a level playing field that allows talents to become the best version of themselves. ${ }^{28}$ Consequently, it encourages the creation of an ecosystem that allows innovation and efficiency.

In contrast to inclusive economic institutions, another type of economic institution is identified by rent-seeking activities within the economic system. Rent-seeking activity is indicated by the acts of an individual or a group to increase their earnings by influencing the legislation and policymaking process. By creating deep connections to the top government officials, the rent-seekers can obstruct and control the normal supply and demand chain according to their will. ${ }^{29}$

Acemoglu and Robinson called economic structures is dominated by rentseekers as extractive economic institutions. The term indicated its core activity, which extracts prosperity and wealth for the benefit of a few. ${ }^{30}$ Extractive political institutions, which concentrate political power among the elites with less transparency, also enable and develop these extractive economic institutions. In practice, the interest of the political elites is determining the economic activities, typically by extracting available resources from the whole society. ${ }^{31}$ As the economic and political system loosens the power of the government, these elites emerge as the rentseekers. ${ }^{32}$ The extractive economic institutions emphasize the collusion between the corrupted political system and the closed economic system.

A classic political economy model called redistributive combines congruous to such a non-inclusive economic institution is also worth considering. In

27 Daron Acemoglu \& James A Robinson, Why Nations Fail: The Origins of Power, Prosperity, and Poverty (London: Profile Books, Ltd, 2012) at 74.

28 Ibid at 77.

29 Ahmad Erani Yustika, Ekonomi Politik: Pijakan Teoritis dan Kajian Empiris (Malang: Intrans Publishing, 2020) at 43.

30 Acemoglu \& Robinson, supra note 27 at 76.

31 Ibid at 81.

32 Yustika, supra note 29 at 45. 
such a model, economic resources, productive assets, and capital are limited in the hands of a few. A closed political system may create redistributive combines, nurtured by a vague legal system or the absence of the rule of law in the economic system. ${ }^{33}$ As the barriers become more significant, it creates a more decisive impetus to influence the government policy for these rent-seekers benefit. In the end, there are two proposed actions to prevent such extractive activities, which are by removing the barriers to enter the market and by increasing the competition in it. ${ }^{34}$ Rent-seekers will flourish when access to enter the market is blocked.

The discourse on economic democracy within the framework of the Indonesian constitution is often associated with the management of Indonesia's natural resources. ${ }^{35}$ The original article regulated that the state shall control the earth, water, and natural resources of Indonesia and use them to serve the prosperity of the people. ${ }^{36}$ In addition, the constitution designed the economy centrally under the management of the state. The state is given the authority to formulate policies (beleid), to regulate (regelendaad), to administer (bestuurdaad), to manage (beheerdaad), and to supervise resources. ${ }^{37}$ The essential economic sectors and related to the public interests are controlled by the state..$^{38}$ It shows how the provisions of Article 33 of the 1945 Constitution were very focused on extractive economic management. However, in the current technological disruption, economic democracy in Article 33 of the 1945 Constitution should be expanded and be contextualized as the fundamentals for Indonesia's digital economy.

\footnotetext{
33 Ibid at 51.

34 Ibid at 47.

35 Rahardjo, supra note 18 at 100. See also Asshiddiqie, supra note 24 at 273.

36 The 1945 Constitution, supra note 17 at Art. 33 (3).

37 Ananda Prima Yurista, "Implikasi Penafsiran Kembali Hak Menguasai Negara terhadap Pengelolaan Wilayah Pesisir dan Pulau-Pulau Kecil” (2016) 5:3 Jurnal Rechtsvinding: Media Pembinaan Hukum Nasional at 341.

38 The 1945 Constitution, supra note 17 at Art. 33 (2).
} 


\section{THE PRINCIPLE OF NET NEUTRALITY}

\section{A. The Economic Nature of the Internet}

After building the digital economy framework under economic democracy, this study moved to discuss the digital economy's sole infrastructure: the internet. There has been a debate over the economic nature of the internet. Its move from a military innovation into a privately managed resource marks transforming the internet from a government-owned commodity into private goods. This shifting is the critical determiner of the net neutrality proposal. This principle stands as an effort to limit the possibility of predatory acts to emerging businesses and innovation in it.

As already well known, the history of the internet started as a United States military project. In 1966, Defense Advanced Research Projects Agency (DARPA) developed the infant version of the internet under the Advanced Research Projects Agency Network (ARPANET). ${ }^{39}$ It took almost 30 years before the privatization of the internet began. In 1990, the United States National Science Foundation (NSF) conducted a discussion of its privatization. NSF then shut down its NSF Network (NSFNET) in 1995, starting to privatize the internet's backbone..$^{40}$ In Indonesia, the first internet protocol was registered by the University of Indonesia in 1988, under the name Universitas Indonesia Network Laboratory (UINETLAB) (192.41.206/24). Not long after, the first commercial ISP was operating under IndoNet, through a dial-up system, in 1994. One year later, the Department of Post and Telecommunication issued the first ISP license for IndoNet. ${ }^{41}$ The privatizations were rapidly developing as the key infrastructure to the new digital business model.

This new digital business model contains three main characters: informational, global, and networked. The digital business is considered informational since its economic structure and activity are dependent on the actors' ability to produce, develop, and administer knowledge-based

39 Barry M Leiner et al., "A Brief History of the Internet" (1997) Internet Society at 3.

40 Shane Greenstein, How the Internet Became Commercial: Innovation, Privatization, and the Birth of a New Network (New Jersey: Princeton University Press, 2015) at 32.

41 Alcianno Ghobadi Gani, "Sejarah dan Perkembangan Internet di Indonesia" (2013) 5:2 Jurnal Mitra Manajemen at 69. 
information in the most efficient ways. The digital business is considered global, as it is implemented globally through a network between economic actors. The digital business is also networked because productivity and competition between actors are generated and provoked within the abstract network without considering the physical presence. ${ }^{42}$ Castells choose the term informational economy to wrap this whole new economic model.

Indonesia is not a subaltern to the trend. The nation is already paving its way as a major player in the region in the disruptive digital economy. To be noted, more than $73 \%$ of its 274,9 million Indonesian residents in 2021 will be internet users. ${ }^{43}$ In 2020, the total valuation of digital economies in Indonesia reached no less than US $\$ 44$ billion, while the number may triple to US $\$ 124$ billion by $2025 .{ }^{44}$ Indonesia will become the country with the most considerable digital economy value in Southeast Asia.

However, along with its rapid industrial growth, stakeholders still question the ability of Indonesian regulation to adjust to these new trends. Dadzie was suggesting that it took a change in policy and regulation to enable inclusive economic development. ${ }^{45}$ Without such a structural change, nations in the Global South like Indonesia may face a considerable obstacle to innovating and participating globally. ${ }^{46}$ This situation is a problem that occurs in many countries, including Indonesia.

By this point, the transformation brought by the digital economy has its political-economic consequences. The transformation may affect the

${ }^{42}$ Manuel Castells, The Rise of the Network Society: Second Edition with a Nerw Preface (West Sussex: Wiley-Blackwell, 2010) at 77.

43 Galuh Putri Riyanto, "Jumlah Pengguna Internet Indonesia 2021 Tembus 202 Juta," online: <https://tekno.kompas.com/read/2021/02/23/16100057/jumlah-penggunainternet-indonesia-2021-tembus-202-juta>.

${ }^{44}$ Google, et al., "Economy SEA 2020," online: <https://storage.googleapis.com/gwebeconomy-sea.appspot.com/assets/pdf/e-Conomy_SEA_2020_Report.pdf $>$.

45 Kofi Q Dadzie, "Inclusive Economic Development Programs and Consumers' Access to Credit in Emerging Market Economies: The Public Policy Role of Marketing in Rural Bank Programs in Ghana" (2013) 32:1 Journal of Public Policy \& Marketing at 59.

46 Louisa Tomar, ed, Digital Economy Enabling Environment Guide: Key Areas of Dialogue for Business and Policy-makers (Washington DC: CIPE \& NML, 2018) at 43. 
political structure and policies produced and vice versa. ${ }^{47}$ From the political economy perspective, the economy can be seen as a way to act, while politics provide the space to start such an action. ${ }^{48}$ Market mechanisms, prices, and investments are being analyzed by considering the political scene of where such an instrument is enabled.

In terms of digital economics, two keywords link the critical relationship between the economy and the power structure: profitability and competitiveness. Castells stated that the economic actors are mainly motivated by profitability and their business growth on one side of the play. To support such demands, the government will set its orientation to maximize competitiveness in its economic realm. The combination of these two is the critical determinant of technological innovation and productivity growth. ${ }^{49}$ At this point, the digital economy fits with economic democracy in Indonesia. As already discussed, these principles assign the government responsibilities to minimize barriers to entering the market. ${ }^{50} \mathrm{It}$ is aligned to maintain a competitive climate for the business.

\section{B. Net Neutrality}

Net neutrality means that ISPs should treat all contents, data, or information circulating on the internet equally without discrimination. Initially, two types of discrimination may occur in the internet service business scheme. The first is the positive type, where the content or an application gets preferential treatment compared to the others. The second is the negative type when access blockade or bandwidth reduction is hindering a content distribution. ${ }^{51}$ The advocacy of net neutrality tries to tackle both issues.

Initially, net neutrality had two derived meanings. First, content traffic on the internet should run without a hitch, regardless of the content, sender,

\footnotetext{
47 Yustika, supra note 29 at 2.

48 Ibid at 7.

49 Castells, supra note 42 at 94.

50 Yustika \& Baksh, supra note 25 at 51.

51 Yosuadi, supra note 5 at 2.
} 
or application. In this framework, internet access is considered a fundamental right that lies inherently in individuals. Second, like an order that prevents ISPs from favoritism over contents, it's faster delivery than other types of content sharing the same network. ${ }^{52}$ The latter is mainly embraced in the United States and became the main conceptual framework for this research.

According to $\mathrm{Wu}$, net neutrality aims to create and maintain a fair and competitive climate on the internet as a business playing field managed by the private sector. Therefore, the space must be neutral so that its competition remains meritocratic..$^{53}$ The presence of regulation by the government aims to stop the short-term interests of the playing field owner from preventing the best product or service from reaching its users.

One of the further proposals from net neutrality is zero-pricing to enter the internet for developers. It postulates a prohibition for ISPs to charge developers and internet content creators fees for sending information to consumers. ${ }^{54}$ According to Lee and $\mathrm{Wu}$, the internet network design does not differentiate content providers and their users. Consequently, content providers can reach other users, who can also act like users. ${ }^{55}$ This system prevents additional fees from being charged to them.

Legal practitioners in Indonesia have already identified several issues to the competition in the digital business scene. First, the potential for abuse of dominant position. This dominant position may give economic actors significant market power through control and full access to consumer data. Second, the potential for cartels or deals. Third, controls over mergers,

52 Ashley Packard, Digital Media Law, 2nd Edition (Sussex: John Wiley \& Sons Inc., 2013) at 146.

53 Tim Wu, "Network Neutrality, Broadband Discrimination" (2003) 2:2 Journal on Telecommunications and High Technology Law at 146.

54 Hemphill, supra note 1 at 137.

55 Robin S Lee \& Tim Wu, "Subsidizing Creativity through Network Neutrality: ZeroPricing and Net Neutrality" (2009) 23:3 Journal of Economic Perspectives at 2009. 
acquisitions, and consolidations. ${ }^{56}$ Net neutrality then added another dimension over the competitiveness issues in the digital business.

The problems that raise net neutrality advocacy are not entirely a whole new concern. Before net neutrality, scholars have discussed several technical principles for better policies, which may drive the nature of the internet as a level playing field and a sandbox for innovation. For example, Lessig proposed the end-to-end principle by referring to the internet as a network of networks that runs through privately owned wires. The end-to-end principle emphasizes that the network should be conditioned as a "stupid network," as it cannot distinguish the information or data passing its 'body'. ${ }^{57}$ It prevents the network from automatically discriminating against such things. In short, the internet is designed to be transparent to applications, so it constitutes internet transparency. This transparent nature enables innovation and creativity on the internet. As the network's intelligence relies on the end users, millions of internet users worldwide decentralize innovation into their hands. ${ }^{58}$ Consequently, it lowers the cost to produce and generate new innovative ideas.

Private actors manage most internet services, and the government is responsible for requiring transparency in data-driven algorithmic technology..$^{59}$ Brown and Bagley believed transparency has an essential role in creating incentives to improve consumers' literacy over a product and prevent unlawful acts on the internet, besides the transparency nature as fundamental to innovation. ${ }^{60}$ It should constitute the market competition

56 Fitri Novia Heriani, "Ini Potensi Pelanggaran Persaingan Usaha di Era Digital," online: <https://www.hukumonline.com/berita/baca/lt6006b094f0131/ini-potensipelanggaran-persaingan-usaha-di-era-digital/?page $=1>$.

57 Lawrence Lessig, The Future of Ideas: The Fate of the Commons in a Connected World (New York: Random House, 2001) at $34 \& 38$.

58 Lawrence B Solum \& Minn Chung, "The Layers Principle: Internet Architecture and the Law" (2004) 79:3 Notre Dame Law Review at 832.

59 Serge Abiteboul \& Julia Stoyanovich, "Transparency, Fairness, Data Protection, Neutrality: Data Management Challenges in the Face of New Regulation" (2019) 11:3 ACM Journal of Data and Information Quality at 2.

${ }^{60}$ Justin S Brown \& Andrew W Bagley, "Neutrality 2.0: The Broadband Transition to Transparency" (2015) 25:3 Fordham Intellectual Property, Media, and Entertainment Law Journal at 659. 
and user attitude. ${ }^{61}$ Then, transparency stands as a political remedy to enact net neutrality.

\section{NET NEUTRALITY REGULATIONS IN SEVERAL COUNTRIES}

\section{A. Net Neutrality in the United States}

As pointed out above, the United States has become the pioneer in the discussion of net neutrality. The Federal Communication Commission (FCC) of the United States has implemented the principle into formal regulations. However, these policies have been overturned repeatedly, either by court decisions or by leadership changes within the FCC. Net neutrality is strongly associated with an attempt to regulate ISPs and broadband policy. ${ }^{62}$ The long journey of the net neutrality policy in the United States is started by the confusion over the ISP's status under The Communication Act, whether it is information services or common carriers. The second categorization allows the FCC to apply a comprehensive regulatory approach to ISPs. ${ }^{63}$ In other words, the choice between information services or common carriers may affect the FCC jurisdiction over ISPs.

Common carriers are well-known public services guidance from common law systems. Common carriers are preventing a public carrier from treating its payload differently and discriminatively. In short, everything a carrier brought should be treated equally. In contrast, a private carrier can collect profit by discriminating against its payload based on its ability to pay. ${ }^{64}$ The common carrier's policy has three primary elements. First, profit control, as the regulated carriers are not to exceed to gain a reasonable return on their

61 Ibid at 660 .

${ }^{62}$ Mohamed El Amrani, et al., "The Competition Between ISPs in the presence of the Net Neutrality" (2017) 6:3 International Journal of Informatics and Communication Technology (IJ-ICT) at 166.

63 Babette EL Boliek, "FCC Regulation Versus Antitrust: How Net Neutrality is Defining the Boundaries" (2011) 52:5 Boston College Law Review at 1643.

${ }^{64}$ Jacob Geffs, "Statutory Definitions of Public Utilities and Carriers" (1937) 12:4 Notre Dame Law Review at 376-377. 
investment. Second, entry control, where the regulated carriers need to obtain a license from the regulatory bodies before serving the public. Third, control over price structure, where the carriers are not allowed to discriminate their customer through rate differentiation. ${ }^{65}$ These characteristics conditioned common carriers to focus on providing equal service to their users rather than pursuing profit margins.

Even after The Telecommunications Act was enacted in 1996, the ISP's position is still blurring. During this uncertainty, FCC promoted four principles that supported the idea of free and open internet and fair competition between ISPs. ${ }^{66}$ Even though these principles were not regulated as a formal FCC policy. ${ }^{67}$ In 2007, several reports emerged from Comcast users that noticed a limitation to access BitTorrent. Associated Press conducted several independent testings, which later confirmed the reports. Along with Free Press, the FCC then filed an official complaint against Comcast. FCC was ordering Comcast to clarify its traffic management system and develop a new policy of non-discriminatory practices. Comcast rejected the decision and sued the FCC. The United States Courts of Appeal then decided that FCC had no jurisdiction for implementing the decisions. ${ }^{68}$ This ruling ends the first phase of the FCC's efforts to implement net neutrality.

FCC then proposed Open Internet Order in 2010. It contains three basic rules of net neutrality: transparency, where ISPs are encouraged to disclose their network management system voluntarily; no blocking, to ensure ISPs not practicing discriminative actions to its users; and no unreasonable discrimination, to ensure the users' rights to access the internet without

65 Richard Posner, Economic Analysis of Law: Third Edition (Philadelphia: Wolter \& Kluwer, 1986) at 320.

66 Robbie Troiano, "Assessing the Current State of Net Neutrality and Exploring Solutions in Creating and Maintaining Open, Available, and Innovative Internet and Broadband Services" (2019) 14:2 Journal of Business \& Technology Law at 560-561.

67 Ibid at 561.

68 DeAgostino, supra note 2 at 93. 
unlawful throttling. ${ }^{69}$ The new policy introduces several new rights, including access to the internet as a level playing field. Open Internet Order also recognizes the ISPs' right to manage their networks under fair business principles; and regulation of mobile broadband. ${ }^{70}$ However, after an appeal submitted by Verizon, the United States Courts of Appeal ruled that FCC had no jurisdiction to enact such a policy. ${ }^{71}$ Interestingly, this second defeat did not make the FCC rest the idea of net neutrality.

In 2015, the FCC made another move by reclassifying ISPs as common carriers under the New Open Internet Order. Within this new policy, FCC implemented three new derivative orders of net neutrality. First, no blocking, where consumers who subscribe to the internet in retail must obtain services and access according to their price for all legal content on the internet. Second, no throttling, where ISPs may not slow down access to legal internet content. Third, no paid prioritization. Paid prioritization occurs when an ISPs accepts payment in any form to set up its network to provide benefits to the manager of certain content, applications, services, or devices. ${ }^{72}$ Not long after its initial release, the New Open Internet Order received objections from ISP's company, leading to a lawsuit to the United States Courts of Appeal.

This time, the court rejected the United States Telecom's argument. On the other hand, the court validated the New Open Internet Order and justified FCC's authority to put the ISPs under the common carrier's category. ${ }^{73}$ After the case, these principles lasted for years until Trump's

69 Alexander Reynolds, "Enforcing Transparency: A Data-Driven Alternative for Open Internet Regulation” (2011) 19:2 CommLaw Conspectus: Journal of Communication Law and Technology Policy at 535.

70 Federal Communications Commission, Preserving the Open Internet Broadband Industry Practices (Wireline Competition, 2010) at 137.

71 Hector R Lozada \& Gary H Kritz, "Net Neutrality Repeal and its Effect on Consumers" (2019) 10:1 International Journal of Business and Social Science at 137.

72 Federal Communications Commission, Protecting and Promoting the Open Internet; Final Rule (Wireline Competition, 2015 at 19740.

73 Christopher R Terry \& Scott Memmel, "Harlem Shake Meets the Cherron Two Step: Net Neutrality Following Mozilla v. FCC" (2020) 15:3 Washington Journal of Law, Technology \& Arts at 174-175. 
administration repealed the newly elected FCC officials. ${ }^{74}$ Since then, FCC has not been issuing new policies to re-implement net neutrality.

\section{B. Net Neutrality in Chile}

Even though pioneering the debates on net neutrality, the United States has not become the first country in the world that implement the principle into a formal regulation. On this occasion, Chile was leapfrogging the United States. It enacted Law No. 20453 of 2010 on Consecrates the Principle of Network Neutrality for Consumers and Internet Users (Net Neutrality Law) in $2010 .{ }^{75}$ It contains three articles that regulate the relations between users and ISPs.

The Net Neutrality Law regulates that any individuals or enterprise that provides commercial internet connectivity services should not arbitrarily block, interfere, discriminate, hinder, or restrict the right of any internet user to use, send, receive or offer any content, application, or legal service through the internet, as well as any other type of legal activity through the network. The ISPs must offer each user an appropriate internet service. ${ }^{76} \mathrm{It}$ is prohibited to arbitrarily distinguish content, applications, or services, based on the source of its origin or ownership. However, public telecommunications concessionaires and ISPs may block access to certain contents, applications, or services if the users request and at their expense. ${ }^{77}$ In no case, this blocking may arbitrarily affect the providers of services and applications provided on the internet.

ISPs may also not limit the user's right to use any kind of instruments or devices on the network, as long as they are legal and do not damage or impair the network or the quality of the service. ISPs are also obliged to offer parental control services for content that violates the law, morals, or

74 Lozada \& Kritz, supra note 71 at 1.

75 Manfred Zink, "Net Neutrality Regulation in the US and Chile: Relevant Aspects Concerning Regulation in Technological Markets From Analyzing Two Concrete Regulatory Experiences" (2013) 3 Derecho Publico Iberoamericano at 163.

76 Law No. 20.453 of 2010 on Consecrates the Principle of Network Neutrality for Consumers and Internet Users, 2010 at Art. 24 H (a).

77 Law No. 20.453 of 2010, supra note 76. 
good custom at the expense of users who request it, as long as users receive advance information in a clear and precise manner regarding the scope of such services. ${ }^{78}$ For the protection of the rights of internet users, the Undersecretary of Telecommunications may sanction the infractions of the legal obligations associated with the implementation and operation of the Net Neutrality Law. ${ }^{79}$ At this point, The Net Neutrality Law also enabled the law enforcement powers to the regulators.

It is interesting to note that in 2014, debates arose over the implementation of net neutrality. The Chilean Government ordered the ISPs to stop offering free access to social media (also known as zero-rated social media apps). The regulator was considering such a strategy violates the Net Neutrality Law, as it indirectly promotes selected social media platforms. ${ }^{80}$ As already mentioned, the Chilean Net Neutrality Law prohibits ISPs from distinguishing contents, applications, or services.

\section{Net Neutrality in Brazil}

Brazil adopted net neutrality through Law No. 12.965 of 2014 (Marco Civil of Internet). It regulates Brazil's internet usage principles, guarantees, rights, and obligations, ${ }^{81}$ including the maintenance and guarantee of net neutrality. It constructs net neutrality to build freedom of expression, an open standard for technology use, personal data protection, cooperation between government bodies, and open governance. ${ }^{82}$ A significant event involving Skype was conditioning and pushing forward the net neutrality regulation. In 2004, Skype users were suspicious that Brazil Telecom

78 Ibid at Art. $24 \mathrm{H}(\mathrm{b}) \&(\mathrm{c})$.

79 Ibid at Art. 24 (I).

80 Bnamericas, "Watchdog: Telcos Offering Free Access to Social Networks Breaks Neutrality Law," online: <https://www.bnamericas.com/en/news/subtel-says-telcos-offeringfree-access-to-social-networks-are-breaking-neutrality-law $>$.

81 Law No. 12.965 of 2014 on Brazilian Civil Rights Framework for the Internet at Art. 1.

82 De Lany, supra note 14 at 358. 
blocked the service. The latter party denied such an accusation but later admitted it. ${ }^{83}$ Another ISP reported implementing a similar approach.

The Brazilian government enacted the Marco Civil of Internet on April 23, 2014. The law ensured a series of users' rights related to internet activities, including the transparency of the internet connection policies by the providers and internet applications. ${ }^{84}$ Only court rulings can waive and put aside this guarantee. Brazil subsequently stipulated that ISPs, on their responsibility for transmission, switching, or routing, are obliged to treat any data package equally without distinguishing content, source, destination, service, terminal, or application. The president will supervise any occurring discrimination or traffic restriction after listening to the opinions of the Internet Management Committee and the National Telecommunications Administration. There will be an evaluation of the necessary technical requirements. ${ }^{85}$ In such incidents, the person in charge must avoid causing harm to users.

ISPs also must act in a proportionate, transparent, and fair manner. ISPs must provide users with preliminary information on traffic management and mitigation measures. This rule includes those related to network security that should provide services under non-discriminatory business conditions and not engage in anti-competitive behavior. ${ }^{86}$ It is also prohibited to block, monitor, filter, or analyze the content of data packages when providing internet connections, whether it is expensive or accessible, and in terms of transmission, switching, or routing. ${ }^{87}$ This strict net neutrality rule limits ISP's companies' potential extra benefit by implementing extra charges for prioritizing contents in the data traffic within their network..$^{88}$ It is not surprising that many of those companies show their objection to Marco Civil of the Internet.

\footnotetext{
83 Ibid at 359.

${ }^{84}$ Law No. 12.965 of 2014, supra note 81 at Art. 7.

85 Ibid at Art. 9 (1).

86 Ibid at Art. 9 (2).

87 Ibid at Art. 9 (3).

88 De Lany, supra note 14 at 359.
} 


\section{Net Neutrality in India}

The debate over net neutrality in India started in 2014. It started as telecommunication enterprises raised concerns about the business intrusion of OTT companies across India. Those OTTs, such as WhatsApp and Skype, affected their core business model that heavily relied on communication services. ${ }^{89}$ On another occasion, Airtel raised its voice against several global internet enterprises, like Google, Facebook, and Amazon..$^{90}$ Airtel considered charging those giants after indirectly advertising their services. ${ }^{91}$

Pros and cons have been rising ever since. Those who supported net neutrality argued that the internet should be considered a basic need. Also, net neutrality was considered an essential foundation for a level playing field on the internet, either its users or emerging businesses. In addition, it was regarded to protect new technology and innovation. Meanwhile, those against it argued that net neutrality would affect free access to the internet, as it suppressed the ISPs' profit margin. ${ }^{92}$ Consequently, it restrained the development of internet infrastructures.

The Indian Government made the first structural move over net neutrality in 2016. At that time, The Telecom Regulatory Authority of India (TRAI) enacted a policy that prevented discrimination in internet services tariffs under the prohibition of discriminatory tariffs for data service regulation, $2016 .{ }^{93}$ The policy stated that ISPs are not allowed to apply the different tariffs-based treatment. The policy did not allow anyone to make illegal dealings with anyone in the interest of applying discriminatory tariffs,

${ }^{89}$ Hassan Habibi Gharakheili, The Role of SDN in Broadband Networks (Berlin: Springer, 2017) at 11.

90 Debarshi Mukherjee \& Sonia Dhir, "Net Neutrality Issues and Different Cross-sections of Society - An Indian Perspective" (2016) 6:2 IPE Journal of Management at 80.

91 Ibid.

92 DS Selvakumar, "Net Neutrality in India-Need of the Hour" (2019) 10:11 International Journal of Mechanical Engineering and Technology at 157.

93 Saif Shahin, "Facing up to Facebook: How Digital Activism, Independent Regulation, and Mass Media Foiled a Neoliberal Threat to Net Neutrality" (2017) 22:1 Information, Communication \& Society at 2. 
except for the tariffs over closed networks. ${ }^{94}$ The regulations also encouraged and permitted the ISPs to cut down data tariffs in accessing emergency services or on the occasion of public emergencies..$^{95}$ In 2018, the Indian Government adopted what is considered the most substantial net neutrality application into regulation. In the newest regulation, TRAI bans the act of blocking, throttling, and zero-rating data policy within a particular scope. Also, it is not allowed to prioritize specific contents or information with a more considerable data speed..$^{96}$ This rule marked a new era in implementing net neutrality in India.

\section{ECONOMIC DEMOCRACY AND THE QUEST OF NET NEUTRALITY IN INDONESIA}

In Indonesia, there are still no regulations that fit the characteristics of a net neutrality, emphasizing the limitation of ISPs in managing content traffic in their network. Neither the Electronic Information and Transaction Law and its amendment nor Anti-monopoly Law adopted net neutrality into its materials. ${ }^{97}$ This situation left a void in Indonesian internet regulation. However, the Electronic Information and Transaction Law contained a regulation on internet throttling and blocking that was almost similar to the main narrative of net neutrality debates. Under the Electronic Information and Transaction Law, the government shall protect public interests from any activity that may threaten public orders due to the mistreatment of internet services. ${ }^{98}$ The law also gives the Indonesian government the authority to prevent illegal internet content dispersion, deployment, and transmission. ${ }^{99}$ In conducting such actions, the law also authorizes the government to terminate internet access or order ISPs. ${ }^{100}$

94 Regulation 2/2016 on the Prohibition of Discriminatory Tariffs for Data Services Regulation at Chapter II Point 3 (1) \& (2).

95 Ibid at Chapter II Point 4.

96 Regulatory Framework on "Net Neutrality" at 2.

97 Permana, supra note 4 at 463.

98 Law 11/2008 on Electronic Information and Transaction and Law 19/2016 at Art. $40(2)$.

99 Ibid at Art. 40 (2a).

${ }^{100}$ Ibid at Art. 40 (2b). 
Under this regulatory construction, ISPs can only carry out the internet access restrictions under the government's instructions.

In the Telkom Group vs. Netflix case, such regulated systems are not strictly applied. Telkom and its mobile ISP subsidiaries, Telkomsel, were immediately blocking Netflix at the beginning of Netflix's presence in Indonesia. The Telkom Group accused Netflix of containing content that was not under moral norms. ${ }^{101}$ Also, Netflix was considered not to have a business license to operate in Indonesia. The Telkom Group took the blocking action by their initiative, without any specific instructions from the Ministry of Communication and Information as regulated by Electronic Information and Transaction Law. ${ }^{102}$ Then, this dispute led to KPPU conducting a preliminary report and starting the trial.

The KPPU's panel made some interesting legal considerations. The panel stated that the Telkom Group was proven to conduct a discriminatory action against Netflix. Supervision of OTT service content that violates the law is considered part of the government's authority. ${ }^{103}$ Until the Telkom Group conducted the blockade, there had been no reports from the public or the related government institutions on Netflix content. The list of Trust Positives managed by the Ministry of Communications and Information Technology did not include the Netflix content. ${ }^{104}$ Thus, Telkom Group has violated the regulations on content blocking.

The panel stated that the Telkom Group had treated Netflix differently than similar companies, even though these companies met the criteria considered by the Telkom Group when blocking Netflix. For example, similar OTT streaming service companies have no representation in Indonesia and contain harmful content. ${ }^{105}$ Even though the discriminatory practice was proven, the panel then stated that what the Telkom Group did was not a form of unfair business competition nor violated antitrust principles. In this case, Netflix is considered not suffering a significant loss

\footnotetext{
1012020 Telkom Group vs. Netflix, supra note 9 at 36.

${ }^{102}$ Ibid at 148.

${ }^{103}$ Ibid at 481.

${ }^{104}$ Ibid at 481-482.

${ }^{105}$ Ibid at 472-473, 478-479, 482.
} 
since there was an increase in Netflix paid users and income in Indonesia from January 2016 to December 2018. ${ }^{106}$ Thus, the KPPU panel decided that the Telkom Group was not convincingly proven to have violated the Anti-Monopoly Law. ${ }^{107}$ KPPU's panel then released the Telkom Group from charges.

Even though the case of Telkom Group vs. Netflix has rested, the discussions remain to continue. KPPU's decision recognized the Telkom Group act of blocking access against Netflix as a form of discrimination. ${ }^{108}$ By referring to the earlier discussion, such an action violates the economic democracy's main principles. Under the guidance of democracy, the policymaker should formulate the economic policies to enable a level playing field for economic actors by minimizing barriers to entering the market. Democracy keeps the digital economy inclusive to prevent domination by a few old economic powers, elites, and rent-seekers. Therefore, at this point, economic democracy and net neutrality made their cross-cut. In the United States, Chile, Brazil, and India, discrimination and entry barriers are essential that net neutrality seeks to prevent. Net neutrality was further translated into the order of no blocking, no throttling, and no paid prioritization. ${ }^{109}$ Since its inception, the idea of net neutrality has sought to advocate for a level playing field for innovators and digital business practitioners; discriminatory practices are contrary to that spirit.

Without proper regulation, such a problem experienced by Netflix is very likely to occur against start-ups or platform companies with smaller business scales. ISPs can illegally block or limit bandwidth to access any targeted content or service. KPPU's decision was also addressing these possibilities. ${ }^{110}$ While formal regulation adopts net neutrality, it can support innovation in the digital business ecosystem in Indonesia. In the future, net

\footnotetext{
${ }^{106}$ Ibid at 486.

107 Ibid at 487.

${ }^{108}$ Ibid at 481.

${ }^{109}$ Federal Communications Commission, supra note 72 at 19740. See also Law No. 20.453 of 2010, supra note 76 at Art. 24 H (a). See also Regulation 2/2016 on the Prohibition of Discriminatory Tariffs for Data Services Regulation, supra note 94 at Chapter II Point 3 (1) \& (2).

1102020 Telkom Group vs. Netflix, supra note 9 at 148.
} 
neutrality may prevent discrimination against emerging businesses with huge potential. Then, in the Telkom Group vs. Netflix case, KPPU may argue that the service blockade by Telkom Group did not much affect Netflix's revenue stream. However, such an excuse cannot be generalized in every case. While ISPs apply a similar blocking policy to emerging platforms, it will directly stop their growth, and such unfortunate events may set adverse precedents in Indonesia's innovation.

\section{CONCLUSION}

In the digital disruption era, Indonesia's digital business ecosystem will continue to grow. Along with preparing physical infrastructures such as the internet and electricity and reliable human resources, the government also needs to enact regulations that are non-discriminatory and friendly to innovation. Net neutrality constituted a framework for the internet to become a level playing field for every economic actor. In the United States and across different Global South countries such as Chile, Brazil, and India, net neutrality relies on three orders of no blocking, no throttling, and no paid prioritization. It is congruent with economic democracy as the core guidance for the Indonesian economic system. The study has shown that net neutrality aligns with economic democracy, as the first enables meritocracy and fair competition within the internet. Without net neutrality, ISPs have the potential to carry out arbitrary actions and conduct an abuse of power against the internet contents, platforms, and services, for their business interests. Therefore, the government needs to consider adopting net neutrality into formal law seriously.

\section{ACKNOWLEDGEMENTS}

None.

\section{COMPETING INTEREST}

The author declared that he has no competing interests. 


\section{REFERENCES}

Abbas, Tarmizi \& Win Konadi Manan, "Keterkaitan Antara Demokrasi Politik, Demokrasi Ekonomi, dan Sistem Ekonomi Kerakyatan" (2005) XXI:3 Mimbar.

Abiteboul, Serge \& Julia Stoyanovich, "Transparency, Fairness, Data Protection, Neutrality: Data Management Challenges in the Face of New Regulation" (2019) 11:3 ACM Journal of Data and Information Quality.

Acemoglu, Daron \& James A Robinson, Why Nations Fail: The Origins of Power, Prosperity, and Poverty (London: Profile Books, Ltd, 2012).

Anggraeni, Ricca, "Memaknakan Fungsi Undang-Undang Dasar Secara Ideal dalam Pembentukan Undang-Undang" (2019) 48:3 Masalah-Masalah Hukum.

Anugroho, Adhi, Ratih Lestarini \& Tri Hayati, "Analisis Yuridis Terhadap Asas Efisiensi Berkeadilan Berdasarkan Pasal 33 Ayat (4) UUD 1945 dalam Peraturan Perundang-Undangan di Bidang Ketenagalistrikan" (2017) 47:2 Jurnal Hukum \& Pembangunan.

Asshiddiqie, Jimly, Konstitusi Ekonomi (Jakarta: Kompas, 2016).

Boliek, Babette EL, "FCC Regulation Versus Antitrust: How Net Neutrality is Defining the Boundaries" (2011) 52:5 Boston College Law Review.

Bnamericas, "Watchdog: Telcos Offering Free Access to Social Networks Breaks Neutrality Law," online: <https://www.bnamericas.com/en/news/ subtel-says-telcos-offering-free-access-to-social-networks-arebreaking-neutrality-law>.

Brown, Justin S \& Andrew W Bagley, "Neutrality 2.0: The Broadband Transition to Transparency" (2015) 25:3 Fordham Intellectual Property, Media, and Entertainment Law Journal.

Castells, Manuel, The Rise of the Network Society: Second Edition with a New Preface (West Sussex: Wiley-Blackwell, 2010).

Dadzie, Kofi Q, 'Inclusive Economic Development Programs and Consumers' Access to Credit in Emerging Market Economies: The Public Policy Role of 
Marketing in Rural Bank Programs in Ghana" (2013) 32:1 Journal of Public Policy \& Marketing.

De Lany, Nisha K, "From a Developing Country's Perspective: Is Net Neutrality a Non-Issue for South Africa?" (2017) 47:2 The University of the Pacific Law Review.

DeAgostino, Sarah, "Neutrality in the Modern World: Internet Regulation's Impact on Economics and Society" (2020) 10:1 Notre Dame Journal of International \& Comparative Law.

Dewantara, Reka, "Rekonseptualisasi Asas Demokrasi Ekonomi dalam Konstitusi Indonesia” (2014) 7:2 Arena Hukum.

El Amrani, Mohamed, "The Competition Between ISPs in Presence of the Net Neutrality" (2017) 6:3 International Journal of Informatics and Communication Technology (IJ-ICT).

Federal Communications Commission, Preserving the Open Internet Broadband Industry Practices (Wireline Competition, 2010).

Federal Communications Commission, Protecting and Promoting the Open Internet; Final Rule (Wireline Competition, 2015.

Gani, Alcianno Ghobadi, "Sejarah dan Perkembangan Internet di Indonesia" (2013) 5:2 Jurnal Mitra Manajemen.

Geffs, Jacob, "Statutory Definitions of Public Utilities and Carriers" (1937) 12:4 Notre Dame Law Review.

Gharakheili, Hassan Habibi, The Role of SDN in Broadband Networks (Berlin: Springer, 2017).

Google, "Google Trends Indonesia: Net Neutrality," online: <https://trends. google.com/trends/explore?q=net\%20neutrality\&geo=ID>.

Google, "Economy SEA 2020", online: <https://storage.googleapis.com/ gweb-economy-sea.appspot.com/assets/pdf/e-Conomy_SEA_2020_ Report.pdf>.

Greenstein, Shane, How the Internet Became Commercial: Innovation, Privatization, and the Birth of a New Network (New Jersey: Princeton University Press, 2015). 
Hakim, Muhammad Helmy, "Pergeseran Orientasi Penelitian Hukum: Dari Doktrinal ke Sosio-Legal" (2016) 16:2 Syariah: Jurnal Hukum dan Pemikiran.

Hart, Jeffrey A, "The Net Neutrality Debate in the United States" (2011) 8:4 Journal of Information Technology \& Politics.

Hemphill, C Scott, "Network Neutrality and the False Promise of Zero-Price Regulation" (2008) 25:2 Yale Journal on Regulation.

Heriani, Fitri Novia, "Ini Potensi Pelanggaran Persaingan Usaha di Era Digital", online: <https://www.hukumonline.com/berita/baca/lt6006b 094f0131/ini-potensi-pelanggaran-persaingan-usaha-di-eradigital/?page $=1>$.

Lee, Robin S \& Tim Wu, "Subsidizing Creativity through Network Neutrality: Zero-Pricing and Net Neutrality" (2009) 23:3 Journal of Economic Perspectives.

Leiner, Barry M, et al., "A Brief History of the Internet" (1997) Internet Society.

Lessig, Lawrence, The Future of Ideas: The Fate of the Commons in a Connected World (New York: Random House, 2001).

Lozada, Hector R \& Gary H Kritz, "Net Neutrality Repeal and its Effect on Consumers" (2019) 10:1 International Journal of Business and Social Science.

Mezak, Meray Hendrik, "Jenis, Metode, dan Pendekatan Dalam Penelitian Hukum" (2006) 3:3 Law Review Fakultas Hukum Universitas Pelita Harapan.

Mukherjee, Debarshi \& Sonia Dhir, "Net Neutrality Issues and Different Cross-sections of Society - An Indian Perspective" (2016) 6:2 IPE Journal of Management.

Packard, Ashley, Digital Media Law, 2nd Edition (Sussex: John Wiley \& Sons Inc., 2013).

Permana, Rizky Banyualam, "Network Neutrality: Standar Baru dalam Tata Kelola Internet?" (2019) 31:3 Mimbar Hukum. 
Posner, Richard, Economic Analysis of Law: Third Edition (Philadelpia: Wolter \& Kluwer, 1986).

Rahardjo, M Dawam, Nalar Ekonomi Politik Indonesia (Bogor: IPB Press, 2011).

Reynolds, Alexander, "Enforcing Transparency: A Data-Driven Alternative for Open Internet Regulation" (2011) 19:2 CommLaw Conspectus: Journal of Communication Law and Technology Policy.

Riyanto, Galuh Putri, "Jumlah Pengguna Internet Indonesia 2021 Tembus 202 Juta", online: <https://tekno.kompas.com/read/2021/02/23/161 00057/jumlah-pengguna-internet-indonesia-2021-tembus-202-juta>.

Selvakumar, DS, "Net Neutrality in India-Need of the Hour" (2019) 10:11 International Journal of Mechanical Engineering and Technology.

Shahin, Saif, "Facing up to Facebook: How Digital Activism, Independent Regulation, and Mass Media Foiled a Neoliberal Threat to Net Neutrality" (2017) 22:1 Information, Communication \& Society.

Singh, Jasbir, "Growth and Potential of Wireless Internet User in Rural India" (2021) 58:2 Psychology and Education: An Interdisciplinary Journal.

Solum, Lawrence B \& Minn Chung, "The Layers Principle: Internet Architecture and the Law" (2004) 79:3 Notre Dame Law Review.

Terry, Christopher R \& Scott Memmel, "Harlem Shake Meets the Chevron Two Step: Net Neutrality Following Mozilla v. FCC" (2020) 15:3 Washington Journal of Law, Technology \& Arts.

Tomar, Louisa, ed, Digital Economy Enabling Environment Guide: Key Areas of Dialogue for Business and Policy-makers (Washington DC: CIPE \& NML, 2018).

Troiano, Robbie, "Assessing the Current State of Net Neutrality and Exploring Solutions in Creating and Maintaining Open, Available, and Innovative Internet and Broadband Services" (2019) 14:2 Journal of Business \& Technology Law.

Wu, Tim, "Network Neutrality, Broadband Discrimination" (2003) 2:2 Journal on Telecommunications and High Technology Law. 
Yosuadi, Dolok, "Problematika Prinsip Net Neutrality Berkenaan Layanan Jasa Netflix Pada Regulasi Nasional Indonesia" (2021) 7:1 Morality: Jurnal Ilmu Hukum.

Yurista, Ananda Prima, "Implikasi Penafsiran Kembali Hak Menguasai Negara terhadap Pengelolaan Wilayah Pesisir dan Pulau-Pulau Kecil" (2016) 5:3 Jurnal Rechtsvinding: Media Pembinaan Hukum Nasional.

Yustika, Ahmad Erani, Ekonomi Politik: Pijakan Teoritis dan Kajian Empiris (Malang: Intrans Publishing, 2020).

Yustika, Ahmad Erani \& Rukavina Baksh, Kebijakan Ekonomi: Regulasi, Institusi, Konstitusi (Malang: Intrans Publishing, 2021).

Zink, Manfred, "Net Neutrality Regulation in the US and Chile: Relevant Aspects Concerning Regulation in Technological Markets From Analyzing Two Concrete Regulatory Experiences" (2013) 3 Derecho Publico Iberoamericano. 
416 | Economic Democracy and the Quest of Net Neutrality in Indonesia

This page intentionally left blank 